\title{
Comprehensive Analyses of Cytochrome P450 Monooxygenases and Secondary Metabolite Biosynthetic Gene Clusters in Cyanobacteria
}

\author{
Makhosazana Jabulile Khumalo ${ }^{1}$, Nomfundo Nzuza ${ }^{1}$, Tiara Padayachee ${ }^{1}\left(\mathbb{D}\right.$, Wanping Chen ${ }^{2}$, \\ Jae-Hyuk Yu ${ }^{3,4}\left(\mathbb{D}\right.$, David R. Nelson ${ }^{5, *(1)}$ and Khajamohiddin Syed ${ }^{1, *(1)}$ \\ 1 Department of Biochemistry and Microbiology, Faculty of Science and Agriculture, University of Zululand, \\ KwaDlangezwa 3886, South Africa; khosietens@gmail.com (M.J.K.); nomfundonzuza11@gmail.com (N.N.); \\ teez07padayachee@gmail.com (T.P.) \\ 2 Department of Molecular Microbiology and Genetics, University of Göttingen, 37077 Göttingen, Germany; \\ chenwanping1@foxmail.com \\ 3 Department of Bacteriology, University of Wisconsin-Madison, 3155 MSB, 1550 Linden Drive, Madison, \\ WI 53706, USA; jyu1@wisc.edu \\ 4 Department of Systems Biotechnology, Konkuk University, Seoul 05029, Korea \\ 5 Department of Microbiology, Immunology and Biochemistry, University of Tennessee Health Science Center, \\ Memphis, TN 38163, USA \\ * Correspondence: dnelson@uthsc.edu (D.R.N.); khajamohiddinsyed@gmail.com (K.S.)
}

Received: 22 December 2019; Accepted: 15 January 2020; Published: 19 January 2020

check for updates

\begin{abstract}
The prokaryotic phylum Cyanobacteria are some of the oldest known photosynthetic organisms responsible for the oxygenation of the earth. Cyanobacterial species have been recognised as a prosperous source of bioactive secondary metabolites with antibacterial, antiviral, antifungal and/or anticancer activities. Cytochrome P450 monooxygenases (CYPs/P450s) contribute to the production and diversity of various secondary metabolites. To better understand the metabolic potential of cyanobacterial species, we have carried out comprehensive analyses of P450s, predicted secondary metabolite biosynthetic gene clusters (BGCs), and P450s located in secondary metabolite BGCs. Analysis of the genomes of 114 cyanobacterial species identified 341 P450s in 88 species, belonging to 36 families and 79 subfamilies. In total, 770 secondary metabolite BGCs were found in 103 cyanobacterial species. Only $8 \%$ of P450s were found to be part of BGCs. Comparative analyses with other bacteria Bacillus, Streptomyces and mycobacterial species have revealed a lower number of P450s and BGCs and a percentage of P450s forming part of BGCs in cyanobacterial species. A mathematical formula presented in this study revealed that cyanobacterial species have the highest gene-cluster diversity percentage compared to Bacillus and mycobacterial species, indicating that these diverse gene clusters are destined to produce different types of secondary metabolites. The study provides fundamental knowledge of P450s and those associated with secondary metabolism in cyanobacterial species, which may illuminate their value for the pharmaceutical and cosmetics industries.
\end{abstract}

Keywords: cytochromes P450 monooxygenases; secondary metabolites; Cyanobacteria; biosynthetic gene clusters; gene-cluster diversity percentage; mathematical formula; phylogenetic analysis

\section{Introduction}

Cyanobacteria are thought to be some of the oldest known photosynthetic organisms that played a major role in the evolution of life by contributing to the oxygenation of the earth's atmosphere [1-5]. These Gram-negative photosynthetic prokaryotes also played a significant role in nitrogen and carbon cycles as they are able to fix atmospheric nitrogen and carbon. It is also well known that cyanobacterial 
species are responsible for the evolution of plants on earth owing to their endosymbiotic lifestyle, which led to the development of light-harvesting organelles in plants [6,7]. Cyanobacterial species can be found in diverse terrestrial habitats, ranging from the oceans to fresh-water bodies, soil to desert rocks, and extreme environments such as Antarctic dry valleys, Arctic and thermophilic lakes [8,9].

To survive in a wide range of environments, cyanobacterial species produce diverse natural products comprising both primary and secondary metabolites belonging to the group's non-ribosomal proteins, polyketides, and terpenes and alkaloids. These products have varying activities of anticancer, antiviral, and ultraviolet-protective activities, as well as hepatotoxicity and neurotoxicity $[10,11]$. Many cyanobacterial species are used as model organisms to understand fundamental processes such as photosynthesis, nitrogen fixation, and circadian rhythm [12-14]. Owing to their amenability to gene manipulation, these organisms have been genetically modified/engineered for the production of valuable human compounds $[15,16]$. Despite all their highly beneficial characteristics, cyanobacterial species are also known to cause cyanobacterial blooms in water, resulting in the production of toxins that are harmful to humans, wild and domestic animals [17]. An overview of some of the cyanobacterial species' beneficial and harmful characteristics is presented in Table 1.

Table 1. Some of the cyanobacterial species well-known characteristics.

\begin{tabular}{|c|c|c|}
\hline Species Name & Well Known for & Reference(s) \\
\hline Acaryochloris marina & $\begin{array}{l}\text { Species were isolated from the marine environment and can produce chlorophyll } \mathrm{d} \text { as primary photosynthetic pigment } \\
\text { that is able to use far-red light for photosynthesis. }\end{array}$ & [18] \\
\hline Anabaena sp. WA102 & $\begin{array}{l}\text { Filamentous nitrogen-fixing cyanobacterium that often form blooms in eutrophic water bodies and able to produce a } \\
\text { range of neurotoxic secondary metabolites. }\end{array}$ & [19] \\
\hline $\begin{array}{l}\text { Synechocystis sp. PCC } \\
6803\end{array}$ & $\begin{array}{l}\text { Species found in fresh water and capable of both phototrophic and heterotrophic growth; owing to this ability, it was } \\
\text { one of the most highly studied cyanobacterium for these characteristics. This species lost its nitrogen-fixing ability. }\end{array}$ & [20] \\
\hline $\begin{array}{l}\text { Synechococcus elongatus } \\
\text { PCC } 6301\end{array}$ & $\begin{array}{l}\text { Unicellular, rod-shaped, fresh-water living, obligate photoautotrophic organism that has long been used as a model } \\
\text { organism for photosynthesis research. }\end{array}$ & [21] \\
\hline $\begin{array}{l}\text { Synechococcus sp. } \\
\text { WH8102 }\end{array}$ & $\begin{array}{l}\text { Widely found in marine water across the world. It is well known for its oligotrophic nature, as it can utilize nitrogen } \\
\text { and phosphorus sources. It also developed strategies to conserve limited iron stores by using nickel and cobalt in } \\
\text { some enzymes. Species belonging to the genus Synchococcus are considered generalist compared to Prochlorococcus } \\
\text { species, as they are nutritionally versatile and adapted to different ecological niches. These species developed a unique } \\
\text { type of swimming motility, as they propel in the absence of any demonstrable external organelle. }\end{array}$ & [22] \\
\hline $\begin{array}{l}\text { Thermosynechococcus } \\
\text { elongates }\end{array}$ & $\begin{array}{l}\text { This species is unique among cyanobacterial species, as it grows in hot springs and has an optimal growth } \\
\text { temperature of } 55^{\circ} \mathrm{C} \text {. }\end{array}$ & [23] \\
\hline Cyanobium sp. NIES-981 & $\begin{array}{l}\text { This species is used for standard inhibition tests for toxicants in water, as it fulfills the criteria provided by the } \\
\text { Organization for Economic Co-operation and Development test guidelines. }\end{array}$ & [24] \\
\hline Dactylococcopsis salina & Gas-vacuolate cyanobacterium isolated from Solar Lake, a stratified heliothermal saline pool in Sinai. & [25] \\
\hline Chamaesiphon minutus & It is an epiphyte of fresh water red alga Paralemanea catenata (Rhodophyta). & [26] \\
\hline $\begin{array}{l}\text { Leptolyngbya sp. } \\
\text { NIES-3755 }\end{array}$ & $\begin{array}{l}\text { Species belonging to this genus are found in various environments ranging from soil and fresh water to hypogean } \\
\text { sites. This species was isolated from the soil at the Toyohashi University of Technology, Japan. }\end{array}$ & [27-29] \\
\hline $\begin{array}{l}\text { Halomicronema } \\
\text { hongdechloris }\end{array}$ & $\begin{array}{l}\text { It is the first cyanobacterium to be identified that produces chlorophyll } \mathrm{f} \text { and is isolated from a stromatolite in the } \\
\text { World Heritage site of Shark Bay, Western Australia. }\end{array}$ & {$[30,31]$} \\
\hline $\begin{array}{l}\text { Pseudanabaena sp. } \\
\text { ABRG5-3 }\end{array}$ & It is a semifilamentous, non-heterocystous cyanobacterium isolated from a pond in Japan. & [32] \\
\hline $\begin{array}{l}\text { Prochlorococcus marinus } \\
\text { subsp. marinus } \\
\text { CCMP1375 }\end{array}$ & $\begin{array}{l}\text { Among species of the Prochlorococcus genus, this cyanobacterium is extreme as it can grow at very low light levels in } \\
\text { the ocean. Species belonging to this genus are the smallest known oxygen-evolving autotrophs and dominate the } \\
\text { tropical and subtropical oceanic phytoplankton community. Species in this genus are adapted to different light levels } \\
\text { in the ocean. }\end{array}$ & [33] \\
\hline $\begin{array}{l}\text { Geminocystis sp. } \\
\text { NIES-3709 }\end{array}$ & $\begin{array}{l}\text { Fresh water living cyanobacterium capable of accumulating large amounts of phycoerythrin, light-harvesting antenna } \\
\text { proteins, compared to Geminocystis sp. NIES-3708. }\end{array}$ & [34] \\
\hline Microcystis aeruginosa & $\begin{array}{l}\text { Species belonging to this genus are the most representative of toxic bloom-forming cyanobacteria in eutrophic waters. } \\
\text { M. aeruginosa is well-known for its toxicity by producing various toxic small polypeptides, including microcystin and } \\
\text { cyanopeptolin. }\end{array}$ & [35] \\
\hline $\begin{array}{l}\text { Cyanobacterium sp. Strain } \\
\text { HL-69 }\end{array}$ & It is isolated from the magnesium sulfate-dominated hypersaline Hot Lake in northern Washington. & [36] \\
\hline Crocosphaera watsonii & Nitrogen-fixing cyanobacterium found in oligotrophic oceans adapted to iron and phosphorus limitation. & [37] \\
\hline Crocosphaera subtropica & $\begin{array}{l}\text { Unicellular cyanobacteria capable of fixing atmospheric dinitrogen (diazotroph) in marine environments, like } \\
\text { filamentous cyanobacterial species. }\end{array}$ & [38] \\
\hline Trichodesmium erythraeum & $\begin{array}{l}\text { Filamentous cyanobacterium known as the primary producer and supplier of new nitrogen through its ability to fix } \\
\text { atmospheric dinitrogen (diazotroph) in tropical and subtropical oceans. }\end{array}$ & [39] \\
\hline $\begin{array}{l}\text { Arthrospira (Spirulina) } \\
\quad \text { platensis }\end{array}$ & $\begin{array}{l}\text { Economically important cyanobacterium, an important source of nutrition and medicinal value. This species is } \\
\text { consumed as a source of protein around the world. }\end{array}$ & [40] \\
\hline Planktothrix agardhii & Cyanobacterium forming bloom in eutrophic water and capable of producing toxins. & [41] \\
\hline
\end{tabular}


Table 1. Cont.

\begin{tabular}{|c|c|c|}
\hline Species Name & Well Known for & Reference(s) \\
\hline Moorea producens & $\begin{array}{l}\text { Prolific secondary metabolite producing filamentous tropical marine cyanobacterium. One-fifth of its genome is } \\
\text { devoted to the production of secondary metabolites. }\end{array}$ & [42] \\
\hline Gloeobacter violaceus & Ancient cyanobacterium that lacks thylakoid membranes. & [43] \\
\hline Nostoc sp. PCC 7120 & Filamentous cyanobacterium capable of fixing atmospheric dinitrogen (diazotroph). & [44] \\
\hline Nostoc punctiforme & A facultative heterotroph symbiotic cyanobacterium capable of establishing symbiosis with Anthoceros punctatus. & [45] \\
\hline Nostoc azollae 0708 & A nitrogen-fixing endosymbiont of water fern Azolla filiculoides Lam. & [46] \\
\hline Anabaena sp. strain 90 & $\begin{array}{l}\text { Hepatotoxic bloom-forming cyanobacterium with } 5 \% \text { of its genome devoted to synthesis of small peptides that are } \\
\text { toxic to animals. }\end{array}$ & [47] \\
\hline Calothrix strain $336 / 3$ & $\begin{array}{l}\text { Industrially relevant cyanobacterium capable of producing higher levels of hydrogen (biofuel) compared to N. } \\
\text { punctiforme PCC } 73102 \text { and Nostoc (Anabaena) sp. strain PCC } 7120 \text {. }\end{array}$ & [48] \\
\hline Fischerella sp. NIES-3754 & Cyanobacterium isolated from hot spring in Japan with potential to have thermoresistant optogenetic tools. & [49] \\
\hline $\begin{array}{l}\text { Nodularia spumigena } \\
\quad \text { UHCC } 0039\end{array}$ & Cyanobacterium responsible for Baltic sea brackish water cyanobacterial blooms producing toxins. & [50] \\
\hline
\end{tabular}

Currently, world-wide research continues to identify novel secondary metabolites with potential biotechnological value from cyanobacterial species. These secondary metabolites are usually produced by a set of genes that are clustered in an organism, and these clusters are known as secondary metabolite biosynthetic gene clusters (BGCs) [51]. Among different genes involved in the production of secondary metabolites, P450s occupy a special place, as these enzymes contribute to the diversity of secondary metabolites due to regio- and stereo-specific oxidation of substrates [52,53]. Recent studies in different bacterial populations belonging to the genera Bacillus [54], Streptomyces and Mycobacterium [55,56] revealed the presence of a large number of P450s in secondary metabolite BGCs. A paper published in 2010 [11] reported some P450s present in cyanobacterial species where the authors performed blast analysis using P450s from Nostoc sp. strain PCC 7120 [57] and Synechocystis sp. PCC 6803 [58]. However, to date, a comprehensive comparative analysis of P450s and those associated with secondary metabolism in cyanobacterial species has not been reported. The availability of a large number of cyanobacterial species genomes gives us an opportunity to address these issues. In this study, genome data-mining, annotation and phylogenetic analysis of P450s in 114 cyanobacterial species were performed. The study also reports a comparative analysis of secondary metabolite BGCs in cyanobacterial species and identification of P450s that are part of the different BGCs. Furthermore, a comparative analysis of P450s and secondary metabolite key features of cyanobacterial species with other bacterial species belonging to the genera Bacillus, Streptomyces and Mycobacterium is presented.

\section{Results and Discussion}

\subsection{Cyanobacterial Species Have Lowest Number of P450s}

Analysis of 41 cyanobacterial genera and species belonging to the unclassified Cyanobacteria (Table S1) revealed the presence of P450s in all cyanobacterial genera except in the genera Thermosynechococcus, Atelocyanobacterium and Crocosphaera (Figure 1). This may be due to the lowest number of species genomes being available for analysis in these genera. Furthermore, two species in the unclassified Cyanobacteria group did not have P450s (Figure 1). Analysis of P450s at species level revealed that among 114 species, 88 species had P450s and 26 species did not have P450s in their genomes (Figure 1), indicating that most of the species in different genera had P450s.

In total, 341 P450s were found in 88 cyanobacterial species (Figures 2 and 3, Table S2). The analysis also revealed the presence of $13 \mathrm{P} 450$-fragments and $15 \mathrm{P} 450$ false positives in different cyanobacterial species (Table S2). A list of P450s, P450-fragments, and P450 false positives identified in cyanobacterial species, along with their sequences, is presented in Supplementary Dataset 1 . The occurrence of $\mathrm{P} 450$-fragments and $\mathrm{P} 450$ false positives in organisms is quite common and these sequences were not taken for further analysis. Among cyanobacterial species, Rivularia sp. PCC 7116 has the highest number of P450s (16 P450s), followed by Nostocales cyanobacterium HT-58-2 (13 P450s), and Nostoc flagelliforme (12 P450s) (Figure 3 and Table S2). Most of the cyanobacterial species have a single P450 in their genome (Figure 3). Comparative analysis with other bacterial species revealed that cyanobacterial 
species have the lowest number of P450s compared to Bacillus species, Streptomyces and mycobacterial species (Table 2). Cyanobacterial species have an average of three P450s in their genomes compared to an average of four P450s in Bacillus species [54], 30 P450s in mycobacterial species [59], and 34 P450s in Streptomyces species [55] (Table 2).

$\mathbf{A}$

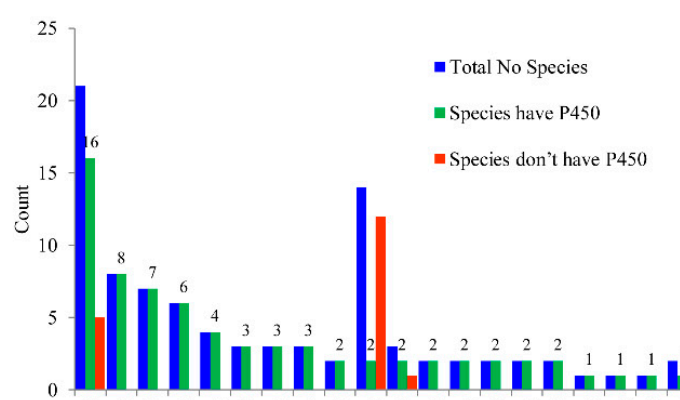

B

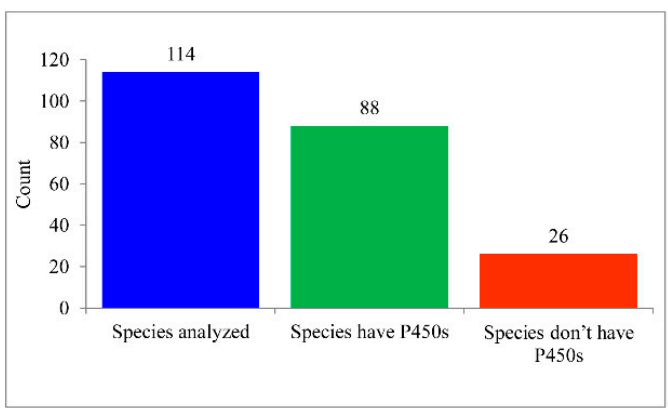

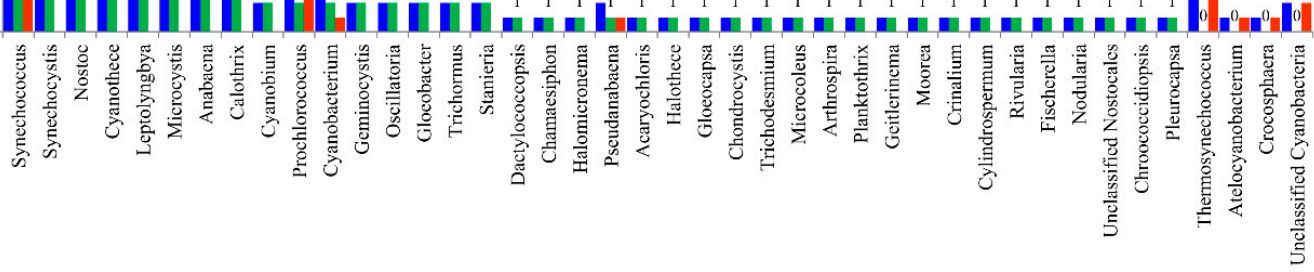

Genus

Figure 1. Analysis of P450s in Cyanobacteria. P450s were analyzed at both the genus level (A) and species level (B). The numbers next to the bars indicate the number of species. In Panel A, only species numbers for the species that have P450s are presented. Detailed information is presented in Tables S1 and S2.

Table 2. Comparative analysis of key features of P450s in different bacterial species.

\begin{tabular}{|c|c|c|c|c|}
\hline & Cyanobacterial Species & Bacillus Species & Mycobacterial Species & Streptomyces Species \\
\hline Total No. of Species Analyzed & 114 & 128 & 60 & 48 \\
\hline No. of P450s & 341 & 507 & 1784 & 1625 \\
\hline No. of Families & 36 & 13 & 77 & 144 \\
\hline No. of Subfamilies & 79 & 28 & 132 & 377 \\
\hline Dominant P450 family & CYP110 & CYP107 & CYP125 & CYP107 \\
\hline No. of BGCs * & 770 & 1098 & 898 & 1461 \\
\hline Types of BGCs & 73 & 33 & 18 & 159 \\
\hline No. of P450s Part of BGCs & 27 & 112 & 204 & 554 \\
\hline Average No. of P450s & 3 & 4 & 30 & 34 \\
\hline P450 Diversity Percentage & 0.09 & 0.02 & 0.07 & 0.18 \\
\hline Average No. of BGCs & 7 & 9 & 15 & 30 \\
\hline Gene Cluster Diversity Percentage & 0.08 & 0.02 & 0.03 & 0.23 \\
\hline Percentage of P450s Part of BGCs & 8 & 22 & 11 & 34 \\
\hline Reference & This work & [54] & {$[55,59]$} & [55] \\
\hline
\end{tabular}

Note: ${ }^{*} 103$ cyanobacterial species gave results with anti-SMASH (antibiotics \& Secondary Metabolite Analysis Shell). Eleven species genomes did not give results. Detailed information on gene clusters is presented in Table S2. 


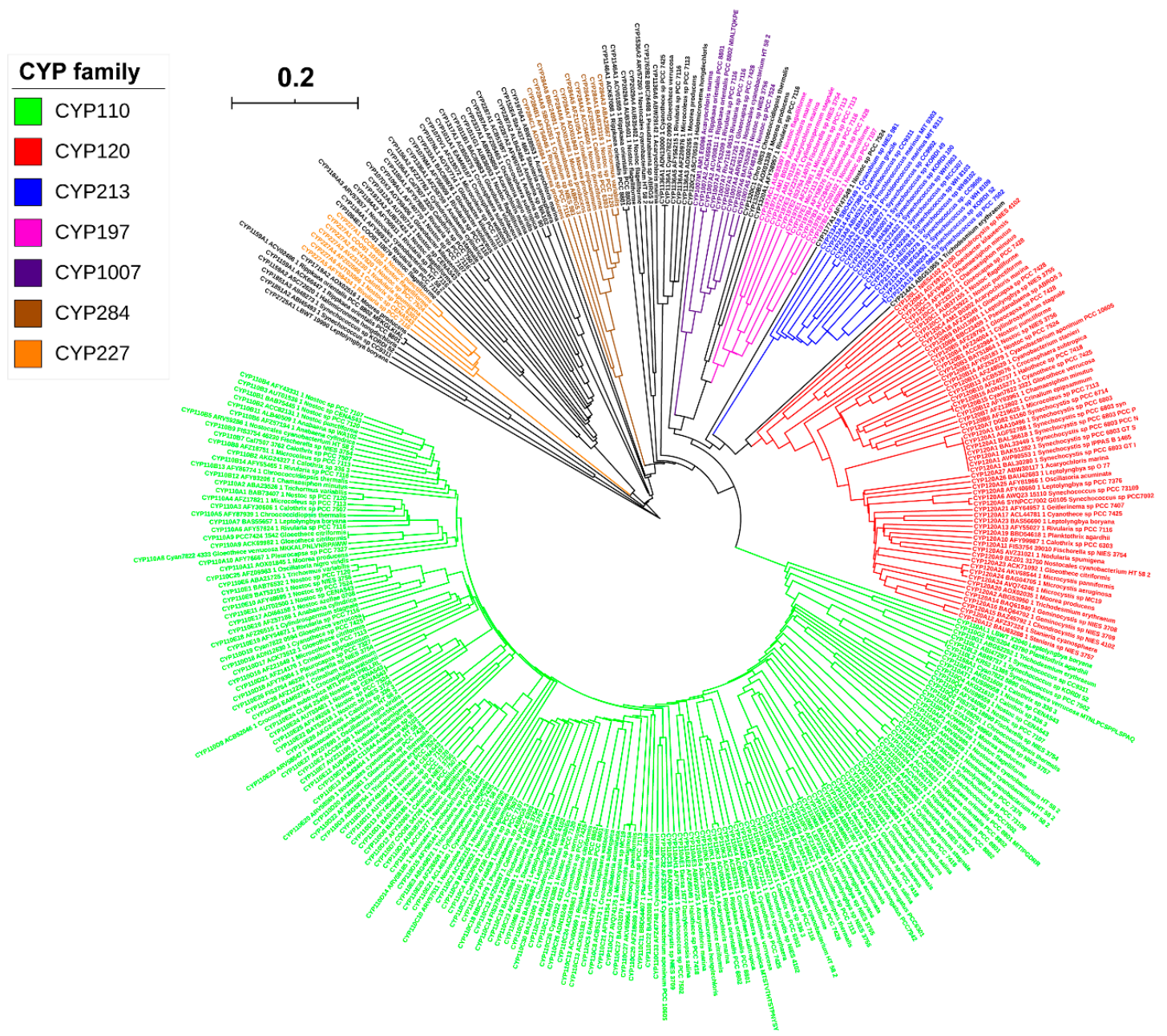

Figure 2. Phylogenetic analysis of cyanobacterial species P450s. Dominant P450 families are indicated in different colours. A high-resolution phylogenetic tree is provided as Supplementary Dataset 2.

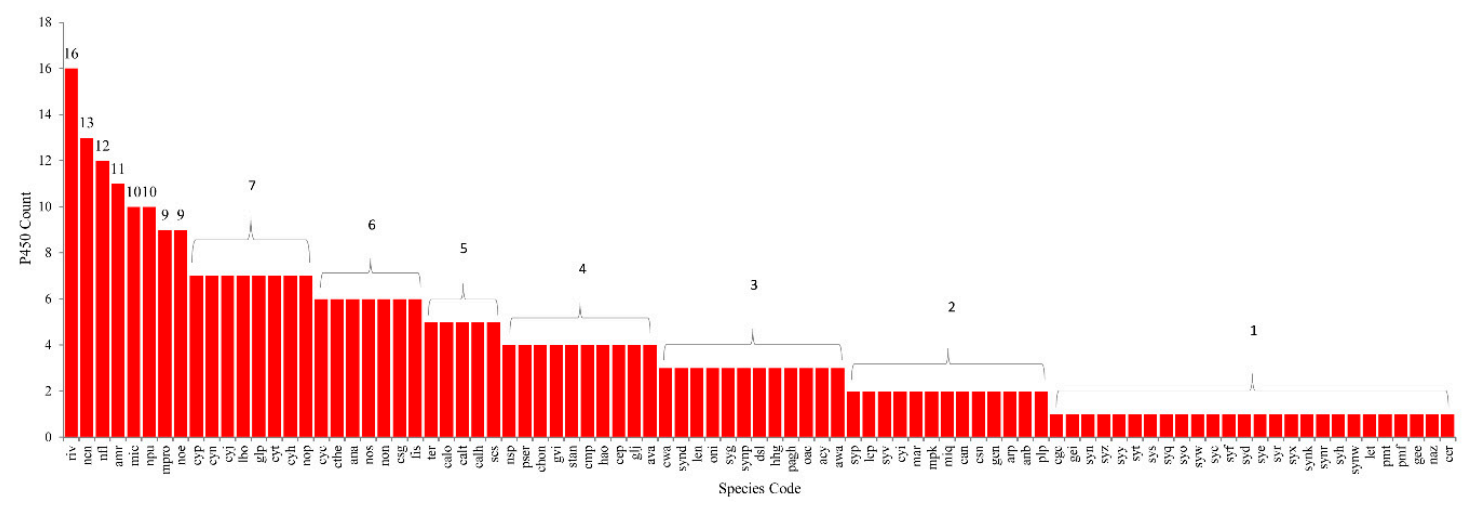

Figure 3. Comparative analysis of P450s in cyanobacterial species. The numbers next to bars indicate the number of P450s in each species. The species names with respect to their codes can be found in Table S2.

\subsection{CYP110 is the Dominant P450 Family in Cyanobacterial Species}

As per the International P450 Nomenclature Committee rules [60-62], $341 \mathrm{P} 450$ s found in 88 cyanobacterial species can be grouped into 36 P450 families and 79 P450 subfamilies (Figure 4 and Table S3). Phylogenetic analysis of cyanobacterial species P450s revealed grouping of P450s belonging 
to the same family together on the tree (Figure 2), indicating the correct assignment of P450 families and subfamilies. Among 36 P450 families, CYP110 has the highest number of P450s (176 P450s), followed by CYP120 (59 P450s), CYP213 (16 P450s) and P450 families, CYP197 and CYP284, which have 11 P450s in each (Figure 4). Comparative analysis of P450 families among different bacterial species revealed that different bacterial species have different dominant P450 families (Table 1). CYP110 is the dominant P450 family in cyanobacterial species, whereas CYP125 is dominant in mycobacterial species and CYP107 in Bacillus species and Streptomyces species (Table 2). The molecular basis for the blooming (P450 family with many members) [63] of certain P450 families is attributed to the species habitat and lifestyle [55]. In addition to this, P450 subfamily-level blooming was observed in cyanobacterial species, where some subfamilies were found to be dominant in a particular family (Table S3). For example, among 26 subfamilies found in the CYP110 family, subfamilies C (34 P450s), E (29 P450s), D (26 P450s) and A (15 P450s) are dominant; among six subfamilies found in CYP120 family, subfamilies A (35 P450s) and B (16 P450s) are dominant (Table S3), indicating the subfamily-level blooming of P450s in cyanobacterial species.

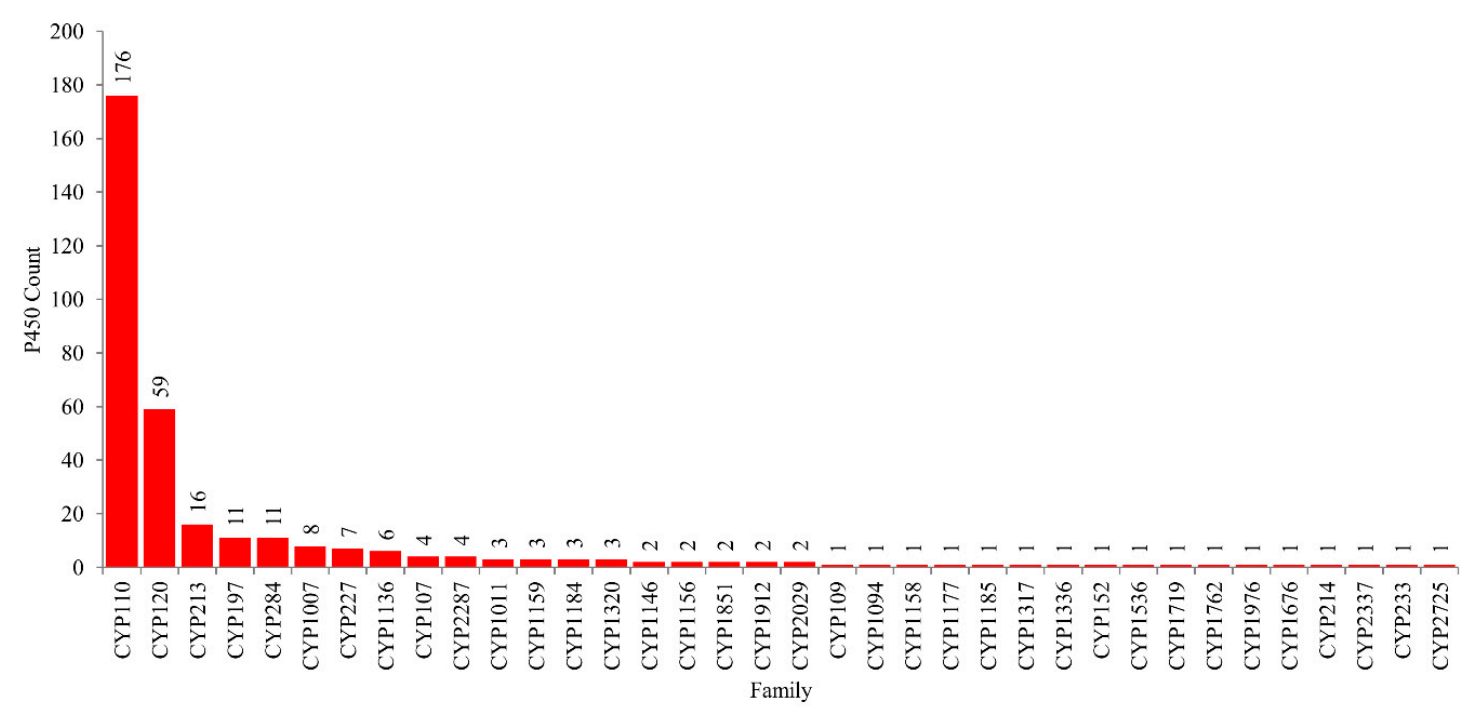

Figure 4. Family level comparative analysis of P450s in the species of Cyanobacteria. The numbers next to the family bar indicate the number of P450s. The data on the number of P450 families, along with subfamilies, are presented in Supplementary Table S3.

Apart from five P450 families, the remaining 31 P450 families in cyanobacterial species have a single-digit number of members (Figure 4). In fact, 17 P450 families have a single P450, indicating high P450 family diversity in cyanobacterial species. This was further confirmed when the P450 diversity percentage was compared among different bacterial species (Table 2). The P450 diversity percentage in cyanobacterial species was found to be highest compared to Bacillus species and mycobacterial species and almost 50\% lower compared to Streptomyces species (Table 2). The highest P450 diversity observed for cyanobacterial species indicates that these P450s might have diverse roles, as was observed for Streptomyces species [55]. However, future functional analysis of cyanobacterial species P450s will provide more evidence on this observation.

P450 family conservation analysis revealed that none of the 36 families were conserved in 88 cyanobacterial species (Figure 5). The P450 profile heat-map revealed that the P450 families CYP110 and CYP120 were found to be a co-presence in most of the cyanobacterial species (Figure 5). Non-conservation of P450 families was also observed in Bacillus species [54], but in the Streptomyces [55] and mycobacterial species [59] quite a large number of P450 families were found to be conserved. 


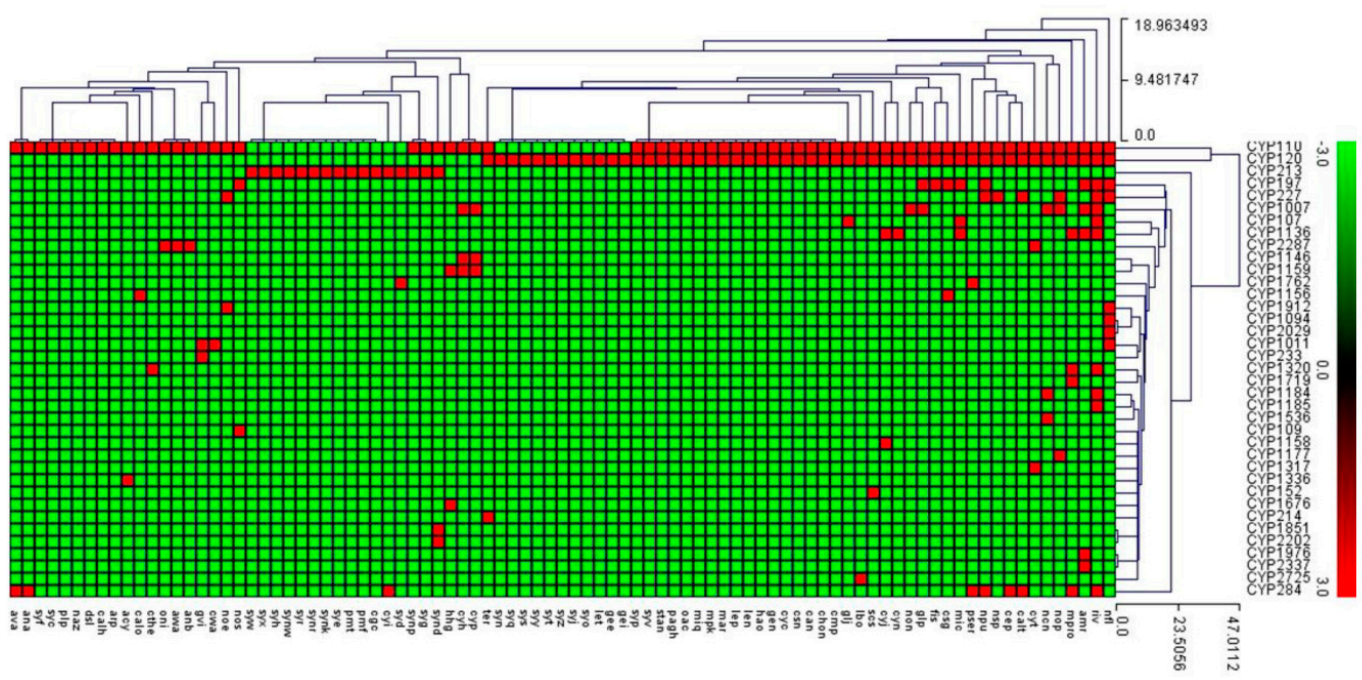

Figure 5. Heat-map of the presence/absence of P450 families in 88 cyanobacterial species. The data is represented as 3 for family presence (red) and -3 for family absence (green). Eighty-nine cyanobacterial species form the horizontal axis and $\mathrm{P} 450$ family numbers form the vertical axis. A detailed table showing P450 family profiles in each of the cyanobacterial species is presented in Supplementary Dataset 3.

\subsection{Cyanobacterial Species Have Lowest Secondary Metabolite Biosynthetic Gene Clusters}

A total of 770 secondary metabolite BGCs were found in 103 cyanobacterial species (Table S2). Species-wise comparative analysis revealed that 29 cyanobacterial species have at least two-digit numbers of secondary metabolites BGCs in their genomes (Figure 6). Among cyanobacterial species, Cylindrospermum stagnale (Csg) and Prochlorococcus marinus MIT 9303 (Pmf) have the highest number of secondary metabolite BGCs (23 BGCs in each), followed by Nostoc sp. CENA543 (Noe) (18 BGCs) and 17 BGCs each in Nostocales cyanobacterium HT-58-2 (Ncn) and P. marinus MIT 9313 (Pmt) (Figure 6). Comparative analysis of secondary metabolite BGCs revealed that cyanobacterial species have the lowest number of secondary metabolite BGCs in their genomes compared to Bacillus species, mycobacterial species and Streptomyces species (Table 2). On average, seven secondary metabolite BGCs were found in cyanobacterial species compared to nine in Bacillus species, 15 in mycobacterial species and 30 in Streptomyces species (Table 2). This indicates that Streptomyces species dominate the production of secondary metabolites and this is the reason why more than $80 \%$ of the antibiotics that are in use today are in fact sourced from Streptomyces species [64].

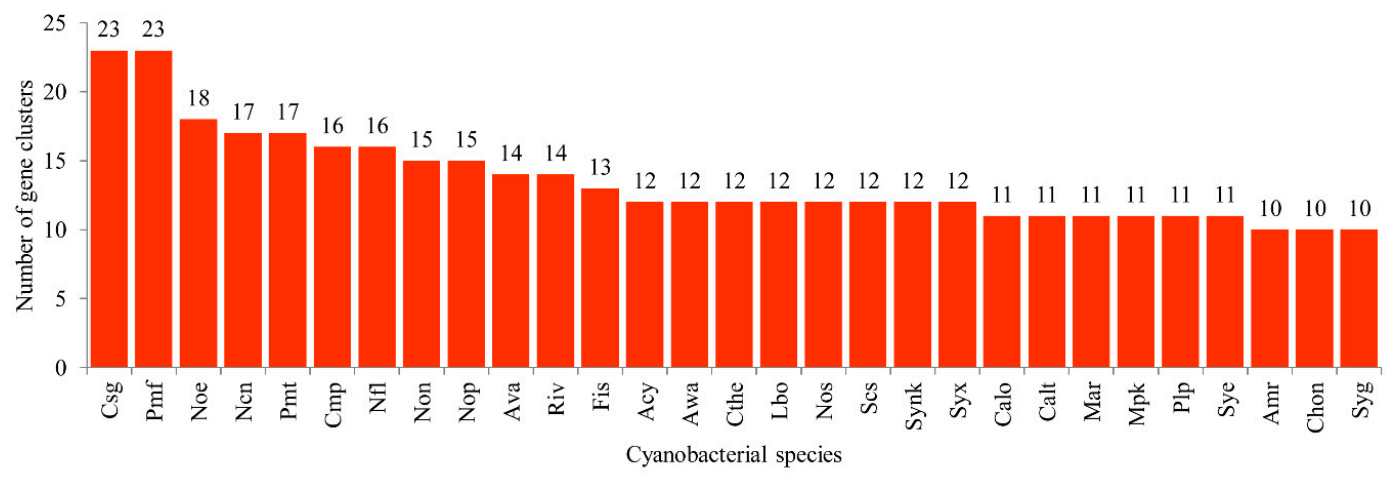

Figure 6. Comparative analysis of secondary metabolite biosynthetic gene clusters (BGCs) in cyanobacterial species. Species with a two-digit number of secondary metabolite BGCs are shown in the figure. The species names with respect to their codes can be found in Table S1. Detailed information on each of the species' secondary metabolite BGCs is presented in Table S2. 


\subsection{Cyanobacterial Species Has Highest Gene Cluster Diversity Percentage Compared to Bacillus and Mycobacterial Species}

Analysis of types of gene clusters in 103 cyanobacterial species revealed the presence of 73 different types of secondary metabolite BGCs (Figure 7 and Table S4). Among secondary metabolite BGCs, terpene BGC is dominant (235 clusters), followed by bacteriocin (183 clusters) and non-ribosomal peptides (NRPS) (64 clusters) (Figure 7). Forty types of BGCs have only a single gene cluster, indicating the highest diversity in types of gene clusters in cyanobacterial species (Figure 7). Comparative analysis of types of BGCs among different bacterial species revealed that cyanobacterial species have the highest number of types of BGCs compared to Bacillus and mycobacterial species, but the lowest compared to Streptomyces species (Table 1).

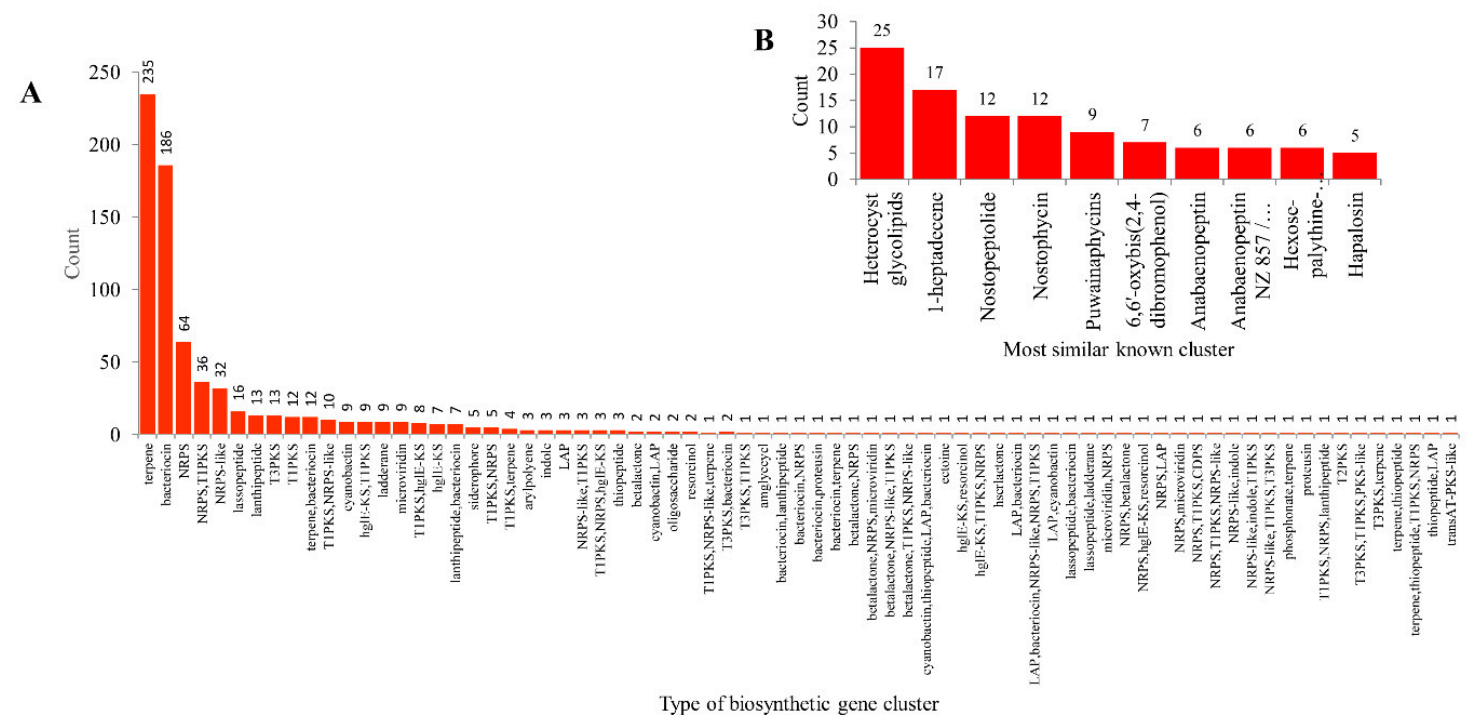

Figure 7. Comparative analysis of types of secondary metabolite biosynthetic gene clusters (BGCs) in 103 cyanobacterial species (A) and most similar known clusters (B). Standard abbreviations representing secondary metabolite BGCs as indicated in anti-SMASH (antibiotics \& Secondary Metabolite Analysis Shell) [65] were used in the figure. Detailed information is presented in Supplementary Table S4.

In order to measure accurate BGC diversity among different bacterial species, we have developed a new equation, similar to the one we developed for P450 diversity percentage calculation [55], with some modification. The formula below will nullify the number of species used and will give an accurate gene cluster diversity percentage comparison between different populations.

$$
\text { Geneclusterdiversitypercentage }=\frac{100 \times \text { Totalnumberoftypesofclusters }}{\text { Totalnumberofclusters } \times \text { numberofspecies }}
$$

Based on the above formula, the gene cluster diversity percentage in cyanobacterial species was found to be four times higher compared to Bacillus and mycobacterial species (Table 2). This indicates that despite cyanobacterial species having the lowest number of gene clusters, these clusters are diverse and destined to produce different types of secondary metabolites. This was evident when looking into the most similar known clusters where, among 770 clusters, only 228 clusters showed similarity to the 79 best known clusters (Figure 7 and Table S4). Among the known similar clusters, only four most similar known clusters are dominant, with 25 (heterocyst glycolipids) 17 (1-heptadecene) and 12 (Nostopeptolide and Nostophycin) (Figure 7 and Table S4). A detailed analysis on most similar known clusters is presented in Supplementary Table S4. The remaining 542 BGCs have no similar known clusters, indicating that these BGCs might encode novel secondary metabolites, possibly with potential biotechnological value. 


\subsection{Few Cyanobacterial Species P450s Found to be Part of Secondary Metabolite Biosynthetic Gene Clusters}

Analysis of P450s that are part of different secondary metabolite BGCs revealed that only a few P450s were part of secondary metabolite BGCs in cyanobacterial species compared to Bacillus, mycobacterial and Streptomyces species (Tables 2 and 3). Only 8\% of P450s are part of BGCs in cyanobacterial species compared to other bacterial species, where $22 \%$ (Bacillus species), $11 \%$ (mycobacterial species) and 34\% (Streptomyces species) of P450s were found to be part of BGCs (Table 2). Among 341 P450s only 27 P450s were found to be part of secondary metabolite BGCs in cyanobacterial species, indicating that cyanobacterial species P450s might play a major role in their primary metabolism. The 27 P450s that are part of BGCs belong to six P450 families (Table 3). P450s belonging to the CYP110 family are dominantly present in BGCs (17 P450s-63\%), followed by CYP213 (4 P450s-15\%), CYP120 (3 P450s-11\%) and a single member found in P450 families CYP1011, CYP1185, and CYP197 (Table 3). A point to be noted is that the CYP110 family is dominantly present in cyanobacterial species, indicating its requirement for the production of secondary metabolites, as the same phenomenon was observed where dominant P450 families were found to be part of BGCs in Bacillus, mycobacterial and Streptomyces species [54,55]. The 27 P450s were found to be part of 10 types of clusters, where nine P450s were found to be part of an NRPS, Type I PKS (polyketide synthase), followed by five P450s that were part of terpene and three P450s that were part of bacteriocin (Table 2). P450s found in each of the clusters and most similar known clusters were presented in Table 3. Analysis of the most similar known clusters revealed that CYP110AH1 from Synechococcus sp. PCC 7502 is certainly involved in the production of anabaenopeptin NZ 857/nostamide, as this P450 NRPS cluster showed $100 \%$ similarity to the gene cluster that produces the metabolite (Table 3). Apart from this match, the percentage similarity to most known clusters is very low and thus the metabolites produced by different gene clusters cannot be predicted.

\subsection{Cyanobacterial Species P450s Functions and Features Resemblance to Eukaryotic P450s}

Functional analysis of a few cyanobacterial species P450s revealed that these P450s have some unusual catalytic diversity and resemblance to eukaryotic P450s. Based on our study, it can safely be predicted that the 27 cyanobacterial species P450s listed in Table 3 are involved in the production of different secondary metabolites. Some of the cyanobacterial species P450 functions against different compounds were elucidated. However, the biological relevance of these reactions is not clear. CYP120A1 from Synechocystis sp. PCC 6803 was found to be the first non-animal retinoic acid hydroxylase [66]. This P450-catalyzed reaction represents a novel modification of retinoids compared to vertebrate CYP26 family P450s. CYP120A1 hydroxylated all-trans-retinoic acid at C16 or C17 positons and converted cis-retinoic acids (9-cis-retinoic acid and 13-cis-retinoic acid), retinal, 3(R)-OH-retinal, retinol, $\beta$-apo-13-carotenone $\left(C_{18}\right)$ and $\beta$-apo-14'-carotenal $\left(C_{22}\right)$ resulted in the formation of the corresponding hydroxyl derivatives [66]. CYP120A1 had the highest preference for all-trans substrates compared to cis- substrates. Among the compounds analysed, CYP120A1 had the highest activity of all-trans-retinoic acids, followed by $\beta$-apo-13-carotenone $\left(\mathrm{C}_{18}\right)$ [66]. CYP110C1 from Nostoc sp. PCC7120 was found to be germacrene A hydroxylase involved in sesquiterpene biosynthesis $[57,67]$. CYP110C1 converted germacrene A into two different products and the predominant product of this reaction was identified as 1,2,3,5,6,7,8,8aoctahydro-6-isopropenyl-4,8a-dimethylnaphth-1-ol [67]. CYP110E1 from the Nostoc sp. strain PCC 7120 was found to be flavone synthase, the first prokaryotic P450 with such activity [68]. CYP110E1 hydroxylated naringenin and (hydroxyl) flavanones into apigenin and (hydroxyl) flavones [68]. CYP110E1 also hydroxylated different compounds such as sesquiterpenes (zerumbone), drugs (ibuprofen and flurbiprofen), and aryl compounds (1-methoxy and 1-ethoxy naphthalene) into novel compounds that are usually difficult to synthesize chemically [68]. CYP110A1 from Nostoc sp. PCC 7120 was predicted to be a fatty acid $\omega$-hydroxylase as the purified P450 binds to long-chain saturated and unsaturated fatty acids [69]. Unlike other prokaryotic P450s, CYP110A1 was found to be associated with membrane fraction, indicating its close resemblance to eukarotic P450s [69]. 
Table 3. Comparative analysis of P450s that are associated with secondary metabolites biosynthetic gene clusters (BGCs). Types of clusters, most similar known cluster and similarity were obtained by submitting individual P450 clusters to anti-SMASH (antibiotics \& Secondary Metabolite Analysis Shell) [65]. Standard abbreviations representing type of clusters as indicated in anti-SMASH [65] were used in the table.

\begin{tabular}{|c|c|c|c|}
\hline P450 Names & Type of Clusters & Most Similar Known Cluster & Similarity \\
\hline CYP213A8 & T3PKS & Xenocyloins & $25 \%$ \\
\hline CYP213A5 & bacteriocin & & \\
\hline CYP213A6 & T3PKS & Colicin V & $2 \%$ \\
\hline CYP110AH1 & NRPS & $\begin{array}{c}\text { Anabaenopeptin NZ } \\
\text { 857/nostamide A }\end{array}$ & $100 \%$ \\
\hline CYP213A3 & bacteriocin & & \\
\hline CYP120C2 & T2PKS & Ambiguine & $6 \%$ \\
\hline CYP110K6 & NRPS & & \\
\hline CYP120A21 & bacteriocin & & \\
\hline CYP110Q3 & NRPS, T1PKS & Hapalosin & $40 \%$ \\
\hline CYP110C17 & terpene & & \\
\hline CYP110C29 & NRPS, T1PKS & Nostophycin & $27 \%$ \\
\hline CYP1011G1 & NRPS, T1PKS & Crocacin & $23 \%$ \\
\hline CYP110AP1 & terpene & & \\
\hline CYP110AT1 & NRPS, T1PKS & Hapalosin & $40 \%$ \\
\hline CYP110Q4 & NRPS, T1PKS & Hapalosin & $40 \%$ \\
\hline CYP110C21 & NRPS-like & Anacyclamide & $14 \%$ \\
\hline CYP197E3 & NRPS, T1PKS & Cryptophycin & $37 \%$ \\
\hline CYP110AG1 & terpene & Hectochlorin & $25 \%$ \\
\hline CYP110E29 & terpene, thiopeptide, T1PKS, NRPS & Nostophycin & $27 \%$ \\
\hline CYP110E18 & terpene, thiopeptide, T1PKS, NRPS & Nostophycin & $27 \%$ \\
\hline CYP110C21 & terpene & & \\
\hline CYP110Q4 & NRPS, T1PKS & Puwainaphycins & $40 \%$ \\
\hline CYP110AT1 & NRPS, T1PKS & Puwainaphycins & $40 \%$ \\
\hline CYP120A13 & ladderane & & \\
\hline CYP1185A1 & lassopeptide, bacteriocin & & \\
\hline CYP110Q2 & NRPS, T1PKS & Hapalosin & $40 \%$ \\
\hline CYP110C14 & terpene & 6,6'-oxybis(2,4-dibromophenol) & $14 \%$ \\
\hline
\end{tabular}

P450s' role in the synthesis of carotenoids, light-harvesting pigments, in cyanobacterial species will help in addressing an evolutionary link between these species and plants since cyanobacterial species considered as precursors of chloroplasts in plants [6,7]. It is well-known that members of the CYP97 P450 family are conserved across plant taxa [70] and involved in the synthesis of carotenoids in plants [71,72]. Furthermore, research in this direction will also help in identifying the biological relevance of P450s in cyanobacterial species.

\section{Materials and Methods}

\subsection{Species and Databases}

In this study, 114 cyanobacterial species belonging to 41 genera and unclassified Cyanobacteria that are available for public use at Kyoto Encyclopaedia of Genes and Genomes (KEGG) [73] were used. Detailed information on different genera and species used in this study is presented in Table S1.

\subsection{Genome Data Mining and Annotation of P450s}

Genome data mining of P450s and their annotation was carried out following the procedure described in the literature [54,55]. Briefly, individual cyanobacterial species proteomes were downloaded from KEGG and subjected to NCBI Batch Web CD-Search Tool analysis [74]. After analysis, the results were analyzed and proteins that belong to the P450 superfamily were selected. The selected proteins were subjected to BLAST analysis at http://bioshell.pl/p450/blast_only.html as part of the P450 
page at http://www.p450.unizulu.ac.za/. Based on the percentage identity to the named homolog P450s, the proteins were then annotated (assigning P450 family and subfamily), following the International P450 Nomenclature Committee rule, i.e., sequences with $>40 \%$ identity were assigned to the same family as named homolog P450 and sequences with $>55 \%$ identity to the same subfamily as named homolog P450 [60-62]. Proteins with less than 40\% identity to a named homolog P450 were assigned to a new P450 family.

\subsection{Phylogenetic Tree Construction of Cyanobacterial Species P450s}

The phylogenetic tree of cyanobacterial species P450s was built using the methodology described elsewhere [54-56]. Firstly, the alignment of cyanobacterial species P450s protein sequences was performed by the MAFFT v6.864 program available at the Trex web server [75] (http://www.trex.uqam. ca/index.php?action=mafft). Then, the alignments were automatically subjected to tree inferring and optimisation by the Trex web server [76]. Briefly, the server inferred the trees with different algorithms, including maximum likelihood, maximum parsimony, neighbor joining, in the library, and searched out the best phylogenetic tree in the least-squares sense. Finally, the best-inferred tree was envisioned and coloured using iTOL [77] (https://itol.embl.de/).

\subsection{Generation of P450 Profile Heat-Maps}

P450 profile heat-maps were generated following the method reported in the literature $[56,78,79]$. The presence or absence of P450s in cyanobacterial species was shown with heat-maps generated using P450 family data. The data were represented as 3 for family presence (red) and -3 for family absence (green). A tab-delimited file was imported into Mev 4.9 (multi-experiment viewer) [80]. Hierarchical clustering using a Euclidean distance metric was used to cluster the data. Eight-nine cyanobacterial species formed the horizontal axis and P450 families formed the vertical axis.

\subsection{Secondary Metabolite Biosynthetic Gene Clusters Analysis}

Secondary metabolite BGCs analysis in cyanobacterial species was carried out following the method as mentioned previously [54,55]. Briefly, individual cyanobacterial species genome IDs (Table S1) were submitted to anti-SMASH (antibiotics \& Secondary Metabolite Analysis Shell) [65] for identification of secondary metabolite BGCs. The gene cluster information generated by anti-SMASH is analyzed for the presence of P450s by manually mining the cluster sequences. Information on the type of cluster, most similar known cluster and percentage similarity to a known cluster is also noted and presented in table format. Among 114 cyanobacterial species, 11 species' genome IDs did not pass through anti-SMASH analysis. Thus, in this study, secondary metabolite BGCs data for 103 species is presented. Lists of species that are not part of the secondary metabolite cluster analysis are presented in Table S5.

\subsection{Data Analysis}

P450 diversity percentage analysis in cyanobacterial species was carried out following the method described elsewhere [55]. P450 diversity percentage is calculated using the formula: P450 diversity percentage $=100 \times$ Total number of P450 families/Total number of P450s $\times$ Number of species. The average number of P450s was calculated using the formula: Average number of P450s $=$ Number of P450s/Number of species. The average number of BGCs was calculated using the formula: Average number of BGCs $=$ Total number of BGCs/Number of species. A new formula was developed in order to calculate gene cluster diversity percentage and is described in Section 2.4.

\section{Conclusions}

Research on harnessing the biotechnological potential of cyanobacterial species is gaining momentum. In this direction, this study is an attempt to provide a complete picture of P450 enzymes 
in different cyanobacterial species as these enzymes are the key players in primary and secondary metabolism of organisms, including the production of different secondary metabolites. Furthermore, providing names for P450s as per International P450 Nomenclature Committee rules enables researchers to make use of the cyanobacterial species P450 names presented in the study. A limited amount of cyanobacterial species $\mathrm{P} 450$ s functional analysis revealed that cyanobacterial species $\mathrm{P} 450$ s are unique in terms of their catalytic activity and they show high resemblance to eukaryotic P450s. Unravelling the role of $\mathrm{P} 450 \mathrm{~s}$ in carotenoid synthesis is necessary to understand their biological relevance in cyanobacterial species and also to address the evolutionary link between these species and plants since cyanobacterial species are considered as precursors of chloroplasts in plants. The mathematical formula presented in this study will enable researchers to conduct accurate comparison of secondary metabolite biosynthetic gene cluster diversity among different organisms. The highest gene cluster diversity observed for cyanobacterial species compared to species belonging to the genera Bacillus and Mycobacterium and the fact that a large number of biosynthetic gene clusters have no similar known clusters indicate that these gene clusters might encode novel secondary metabolites with new biological properties whose potential needs to be explored for the food, cosmetic and pharmaceutical industries.

Supplementary Materials: Supplementary materials can be found at http:/www.mdpi.com/1422-0067/21/2/656/s1.

Author Contributions: Conceptualization, K.S.; data curation, M.J.K., N.N., T.P., W.C., J.-H.Y., D.R.N. and K.S.; formal analysis, M.J.K., N.N., T.P., W.C., J.-H.Y., D.R.N. and K.S.; funding acquisition, K.S.; investigation, M.J.K., N.N., T.P., W.C., J.-H.Y., D.R.N. and K.S.; methodology, M.J.K., N.N., T.P., W.C., J.-H.Y., D.R.N. and K.S.; project administration, K.S.; resources, K.S.; supervision, K.S.; validation, M.J.K., N.N., T.P., W.C., J.-H.Y., D.R.N. and K.S.; visualization, M.J.K., N.N., T.P., W.C., J.-H.Y., D.R.N. and K.S.; writing-original draft, M.J.K., N.N., T.P., W.C., J-H.Y., D.R.N. and K.S.; writing-review and editing, W.C., J.-H.Y., D.R.N. and K.S. All authors have read and agreed to the published version of the manuscript.

Funding: Khajamohiddin Syed expresses sincere gratitude to the University of Zululand Research Committee for funding (Grant No. C686) and to the National Research Foundation (NRF), South Africa for a research grant (Grant No. 114159). Honours students, Makhosazana Jabulile Khumalo (HBG181018376835), Nomfundo Nzuza (MND190626451135) and Tiara Padayachee (MND190619448759) thank the NRF, South Africa for honours bursaries.

Acknowledgments: The authors want to thank Barbara Bradley, Pretoria, South Africa for English language editing.

Conflicts of Interest: The authors declare no conflict of interest. The funders had no role in the design of the study, in the collection, analyses, or interpretation of data, in the writing of the manuscript, or in the decision to publish the results.

\section{References}

1. Bekker, A.; Holland, H.; Wang, P.-L.; Rumble Iii, D.; Stein, H.; Hannah, J.; Coetzee, L.; Beukes, N. Dating the rise of atmospheric oxygen. Nature 2004, 427, 117-120. [CrossRef]

2. Kump, L.R. The rise of atmospheric oxygen. Nature 2008, 451, 277-278. [CrossRef]

3. Shih, P.M. Cyanobacterial evolution: Fresh insight into ancient questions. Curr. Biol. 2015, 25, R192-R193. [CrossRef]

4. Flores, F.G. The Cyanobacteria: Molecular Biology, Genomics, and Evolution; Horizon Scientific Press: Heatherset, UK, 2008.

5. Buick, R. The antiquity of oxygenic photosynthesis: Evidence from stromatolites in sulphate-deficient Archaean lakes. Science 1992, 255, 74-77. [CrossRef]

6. Raven, J.A.; Allen, J.F. Genomics and chloroplast evolution: What did cyanobacteria do for plants? Genome Biol. 2003, 4, 209. [CrossRef]

7. Willis, K.; McElwain, J. The Evolution of Plants; Oxford University Press: Oxford, UK, 2014.

8. Gaysina, L.A.; Saraf, A.; Singh, P. Cyanobacteria in Diverse Habitats. In Cyanobacteria; Elsevier: Amsterdam, The Netherlands, 2019; pp. 1-28.

9. Dvořák, P.; Casamatta, D.A.; Hašler, P.; Jahodářová, E.; Norwich, A.R.; Poulíčková, A. Diversity of the cyanobacteria. In Modern Topics in the Phototrophic Prokaryotes; Springer: Berlin/Heidelberg, Germany, 2017; pp. 3-46.

10. Kultschar, B.; Llewellyn, C. Secondary Metabolites in Cyanobacteria. Second. Metab. Sources Appl. $2018,23$. [CrossRef] 
11. Robert, F.O.; Pandhal, J.; Wright, P.C. Exploiting cyanobacterial P450 pathways. Curr. Opin. Microbiol. 2010, 13, 301-306. [CrossRef]

12. Cohen, S.E.; Golden, S.S. Circadian rhythms in cyanobacteria. Microbiol. Mol. Biol. Rev. 2015, 79, $373-385$. [CrossRef] [PubMed]

13. Jensen, P.E.; Leister, D. Cyanobacteria as an experimental platform for modifying bacterial and plant photosynthesis. Front. Bioeng. Biotechnol. 2014, 2, 7. [CrossRef] [PubMed]

14. Bothe, H.; Schmitz, O.; Yates, M.G.; Newton, W.E. Nitrogen fixation and hydrogen metabolism in cyanobacteria. Microbiol. Mol. Biol. Rev. 2010, 74, 529-551. [CrossRef] [PubMed]

15. Santos-Merino, M.; Singh, A.K.; Ducat, D.C. New applications of synthetic biology tools for cyanobacterial metabolic engineering. Front. Bioeng. Biotechnol. 2019, 7. [CrossRef]

16. Wilde, A.; Dienst, D. Tools for genetic manipulation of cyanobacteria. In Bioenergetic Processes of Cyanobacteria; Springer: Berlin/Heidelberg, Germany, 2011; pp. 685-703.

17. Dittmann, E.; Fewer, D.P.; Neilan, B.A. Cyanobacterial toxins: Biosynthetic routes and evolutionary roots. FEMS Microbiol. Rev. 2013, 37, 23-43. [CrossRef] [PubMed]

18. Swingley, W.D.; Chen, M.; Cheung, P.C.; Conrad, A.L.; Dejesa, L.C.; Hao, J.; Honchak, B.M.; Karbach, L.E.; Kurdoglu, A.; Lahiri, S.; et al. Niche adaptation and genome expansion in the chlorophyll d-producing cyanobacterium Acaryochloris marina. Proc. Natl. Acad. Sci. USA 2008, 105, 2005-2010. [CrossRef] [PubMed]

19. Brown, N.M.; Mueller, R.S.; Shepardson, J.W.; Landry, Z.C.; Morre, J.T.; Maier, C.S.; Hardy, F.J.; Dreher, T.W. Structural and functional analysis of the finished genome of the recently isolated toxic Anabaena sp. WA102. BMC Genom. 2016, 17, 457. [CrossRef] [PubMed]

20. Kaneko, T.; Tanaka, A.; Sato, S.; Kotani, H.; Sazuka, T.; Miyajima, N.; Sugiura, M.; Tabata, S. Sequence analysis of the genome of the unicellular cyanobacterium Synechocystis sp. strain PCC6803. I. Sequence features in the $1 \mathrm{Mb}$ region from map positions $64 \%$ to $92 \%$ of the genome. DNA Res. Int. J. Rapid Publ. Rep. Genes Genomes 1995, 2, 153-166, 191-198.

21. Sugita, C.; Ogata, K.; Shikata, M.; Jikuya, H.; Takano, J.; Furumichi, M.; Kanehisa, M.; Omata, T.; Sugiura, M.; Sugita, M. Complete nucleotide sequence of the freshwater unicellular cyanobacterium Synechococcus elongatus PCC 6301 chromosome: Gene content and organization. Photosynth. Res. 2007, 93, 55-67. [CrossRef]

22. Palenik, B.; Brahamsha, B.; Larimer, F.W.; Land, M.; Hauser, L.; Chain, P.; Lamerdin, J.; Regala, W.; Allen, E.E.; McCarren, J.; et al. The genome of a motile marine Synechococcus. Nature 2003, 424, 1037-1042. [CrossRef]

23. Nakamura, Y.; Kaneko, T.; Sato, S.; Ikeuchi, M.; Katoh, H.; Sasamoto, S.; Watanabe, A.; Iriguchi, M.; Kawashima, K.; Kimura, T.; et al. Complete genome structure of the thermophilic cyanobacterium Thermosynechococcus elongatus BP-1. DNA Res. Int. J. Rapid Publ. Rep. Genes Genomes 2002, 9, 123-130.

24. Yamaguchi, H.; Shimura, Y.; Suzuki, S.; Yamagishi, T.; Tatarazako, N.; Kawachi, M. Complete Genome Sequence of Cyanobium sp. NIES-981, a Marine Strain Potentially Useful for Ecotoxicological Bioassays. Genome Announc. 2016, 4. [CrossRef]

25. Walsby, A.; Van Rijn, J.; Cohen, Y. The biology of a new gas-vacuolate cyanobacterium, Dactylococcopsis salina sp. nov., in Solar Lake. Proc. R. Soc. Lond. Ser. B Biol. Sci. 1983, 217, 417-447.

26. Kučera, P.; Uher, B.; Komárek, O. Epiphytic cyanophytes Xenococcus kerneri and Chamaesiphon minutus on the freshwater red alga Paralemanea catenata (Rhodophyta). Biologia 2006, 61, 11-13. [CrossRef]

27. Hirose, Y.; Fujisawa, T.; Ohtsubo, Y.; Katayama, M.; Misawa, N.; Wakazuki, S.; Shimura, Y.; Nakamura, Y.; Kawachi, M.; Yoshikawa, H.; et al. Complete Genome Sequence of Cyanobacterium Leptolyngbya sp. NIES-3755. Genome Announc. 2016, 4. [CrossRef] [PubMed]

28. Shimura, Y.; Hirose, Y.; Misawa, N.; Osana, Y.; Katoh, H.; Yamaguchi, H.; Kawachi, M. Comparison of the terrestrial cyanobacterium Leptolyngbya sp. NIES-2104 and the freshwater Leptolyngbya boryana PCC 6306 genomes. DNA Res. Int. J. Rapid Publ. Rep. Genes Genomes 2015, 22, 403-412.

29. Bruno, L.; Billi, D.; Bellezza, S.; Albertano, P. Cytomorphological and genetic characterization of troglobitic Leptolyngbya strains isolated from Roman hypogea. Appl. Environ. Microbiol. 2009, 75, 608-617. [CrossRef] [PubMed]

30. Chen, M.; Hernandez-Prieto, M.A.; Loughlin, P.C.; Li, Y.; Willows, R.D. Genome and proteome of the chlorophyll f-producing cyanobacterium Halomicronema hongdechloris: Adaptative proteomic shifts under different light conditions. BMC Genom. 2019, 20, 207. [CrossRef]

31. Chen, M.; Schliep, M.; Willows, R.D.; Cai, Z.L.; Neilan, B.A.; Scheer, H. A red-shifted chlorophyll. Science 2010, 329, 1318-1319. [CrossRef] 
32. Tajima, N.; Kanesaki, Y.; Sato, S.; Yoshikawa, H.; Maruyama, F.; Kurokawa, K.; Ohta, H.; Nishizawa, T.; Asayama, M.; Sato, N. Complete Genome Sequence of the Nonheterocystous Cyanobacterium Pseudanabaena sp. ABRG5-3. Genome Announc. 2018, 6. [CrossRef]

33. Dufresne, A.; Salanoubat, M.; Partensky, F.; Artiguenave, F.; Axmann, I.M.; Barbe, V.; Duprat, S.; Galperin, M.Y.; Koonin, E.V.; Le Gall, F.; et al. Genome sequence of the cyanobacterium Prochlorococcus marinus SS120, a nearly minimal oxyphototrophic genome. Proc. Natl. Acad. Sci. USA 2003, 100, 10020-10025. [CrossRef]

34. Hirose, Y.; Katayama, M.; Ohtsubo, Y.; Misawa, N.; Iioka, E.; Suda, W.; Oshima, K.; Hanaoka, M.; Tanaka, K.; Eki, T.; et al. Complete Genome Sequence of Cyanobacterium Geminocystis sp. Strain NIES-3709, Which Harbors a Phycoerythrin-Rich Phycobilisome. Genome Announc. 2015, 3. [CrossRef]

35. Kaneko, T.; Nakajima, N.; Okamoto, S.; Suzuki, I.; Tanabe, Y.; Tamaoki, M.; Nakamura, Y.; Kasai, F.; Watanabe, A.; Kawashima, K.; et al. Complete genomic structure of the bloom-forming toxic cyanobacterium Microcystis aeruginosa NIES-843. DNA Res. Int. J. Rapid Publ. Rep. Genes Genomes 2007, 14, 247-256. [CrossRef]

36. Mobberley, J.M.; Romine, M.F.; Cole, J.K.; Maezato, Y.; Lindemann, S.R.; Nelson, W.C. Draft Genome Sequence of Cyanobacterium sp. Strain HL-69, Isolated from a Benthic Microbial Mat from a Magnesium Sulfate-Dominated Hypersaline Lake. Genome Announc. 2018, 6. [CrossRef] [PubMed]

37. Bench, S.R.; Heller, P.; Frank, I.; Arciniega, M.; Shilova, I.N.; Zehr, J.P. Whole genome comparison of six Crocosphaera watsonii strains with differing phenotypes. J. Phycol. 2013, 49, 786-801. [CrossRef] [PubMed]

38. Welsh, E.A.; Liberton, M.; Stockel, J.; Loh, T.; Elvitigala, T.; Wang, C.; Wollam, A.; Fulton, R.S.; Clifton, S.W.; Jacobs, J.M.; et al. The genome of Cyanothece 51142, a unicellular diazotrophic cyanobacterium important in the marine nitrogen cycle. Proc. Natl. Acad. Sci. USA 2008, 105, 15094-15099. [CrossRef] [PubMed]

39. Capone, D.G.; Burns, J.A.; Montoya, J.P.; Subramaniam, A.; Mahaffey, C.; Gunderson, T.; Michaels, A.F.; Carpenter, E.J. Nitrogen fixation by Trichodesmium spp.: An important source of new nitrogen to the tropical and subtropical North Atlantic Ocean. Glob. Biogeochem. Cycles 2005, 19. [CrossRef]

40. Fujisawa, T.; Narikawa, R.; Okamoto, S.; Ehira, S.; Yoshimura, H.; Suzuki, I.; Masuda, T.; Mochimaru, M.; Takaichi, S.; Awai, K.; et al. Genomic structure of an economically important cyanobacterium, Arthrospira (Spirulina) platensis NIES-39. DNA Res. Int. J. Rapid Publ. Rep. Genes Genomes 2010, 17, 85-103. [CrossRef]

41. Churro, C.; Azevedo, J.; Vasconcelos, V.; Silva, A. Detection of a Planktothrix agardhii Bloom in Portuguese Marine Coastal Waters. Toxins 2017, 9, 391. [CrossRef]

42. Leao, T.; Castelao, G.; Korobeynikov, A.; Monroe, E.A.; Podell, S.; Glukhov, E.; Allen, E.E.; Gerwick, W.H.; Gerwick, L. Comparative genomics uncovers the prolific and distinctive metabolic potential of the cyanobacterial genus Moorea. Proc. Natl. Acad. Sci. USA 2017, 114, 3198-3203. [CrossRef]

43. Nakamura, Y.; Kaneko, T.; Sato, S.; Mimuro, M.; Miyashita, H.; Tsuchiya, T.; Sasamoto, S.; Watanabe, A.; Kawashima, K.; Kishida, Y.; et al. Complete genome structure of Gloeobacter violaceus PCC 7421, a cyanobacterium that lacks thylakoids. Dna Res. Int. J. Rapid Publ. Rep. Genes Genomes 2003, 10, 137-145. [CrossRef]

44. Kaneko, T.; Nakamura, Y.; Wolk, C.P.; Kuritz, T.; Sasamoto, S.; Watanabe, A.; Iriguchi, M.; Ishikawa, A.; Kawashima, K.; Kimura, T.; et al. Complete genomic sequence of the filamentous nitrogen-fixing cyanobacterium Anabaena sp. strain PCC 7120. DNA Res. Int. J. Rapid Publ. Rep. Genes Genomes 2001, 8, 205-213, 227-253.

45. Ekman, M.; Picossi, S.; Campbell, E.L.; Meeks, J.C.; Flores, E. A Nostoc punctiforme sugar transporter necessary to establish a Cyanobacterium-plant symbiosis. Plant Physiol. 2013, 161, 1984-1992. [CrossRef]

46. Ran, L.; Larsson, J.; Vigil-Stenman, T.; Nylander, J.A.; Ininbergs, K.; Zheng, W.W.; Lapidus, A.; Lowry, S.; Haselkorn, R.; Bergman, B. Genome erosion in a nitrogen-fixing vertically transmitted endosymbiotic multicellular cyanobacterium. PLoS ONE 2010, 5. [CrossRef]

47. Wang, H.; Sivonen, K.; Rouhiainen, L.; Fewer, D.P.; Lyra, C.; Rantala-Ylinen, A.; Vestola, J.; Jokela, J.; Rantasarkka, K.; Li, Z.; et al. Genome-derived insights into the biology of the hepatotoxic bloom-forming cyanobacterium Anabaena sp. strain 90. BMC Genom. 2012, 13, 613. [CrossRef]

48. Isojarvi, J.; Shunmugam, S.; Sivonen, K.; Allahverdiyeva, Y.; Aro, E.M.; Battchikova, N. Draft genome sequence of Calothrix strain 336/3, a novel h2-producing cyanobacterium isolated from a finnish lake. Genome Announc. 2015, 3. [CrossRef]

49. Hirose, Y.; Fujisawa, T.; Ohtsubo, Y.; Katayama, M.; Misawa, N.; Wakazuki, S.; Shimura, Y.; Nakamura, Y.; Kawachi, M.; Yoshikawa, H.; et al. Complete genome sequence of cyanobacterium Fischerella sp. NIES-3754, providing thermoresistant optogenetic tools. J. Biotechnol. 2016, 220, 45-46. [CrossRef] 
50. Teikari, J.E.; Hou, S.; Wahlsten, M.; Hess, W.R.; Sivonen, K. Comparative Genomics of the Baltic Sea Toxic Cyanobacteria Nodularia spumigena UHCC 0039 and Its Response to Varying Salinity. Front. Microbiol. 2018, 9, 356. [CrossRef]

51. Cimermancic, P.; Medema, M.H.; Claesen, J.; Kurita, K.; Wieland Brown, L.C.; Mavrommatis, K.; Pati, A.; Godfrey, P.A.; Koehrsen, M.; Clardy, J.; et al. Insights into secondary metabolism from a global analysis of prokaryotic biosynthetic gene clusters. Cell 2014, 158, 412-421. [CrossRef]

52. Podust, L.M.; Sherman, D.H. Diversity of P450 enzymes in the biosynthesis of natural products. Nat. Prod. Rep. 2012, 29, 1251-1266. [CrossRef]

53. Greule, A.; Stok, J.E.; De Voss, J.J.; Cryle, M.J. Unrivalled diversity: The many roles and reactions of bacterial cytochromes P450 in secondary metabolism. Nat. Prod. Rep. 2018, 35, 757-791. [CrossRef]

54. Mthethwa, B.; Chen, W.; Ngwenya, M.; Kappo, A.; Syed, P.; Karpoormath, R.; Yu, J.-H.; Nelson, D.; Syed, K. Comparative analyses of cytochrome P450s and those associated with secondary metabolism in Bacillus species. Int. J. Mol. Sci. 2018, 19, 3623. [CrossRef]

55. Senate, L.M.; Tjatji, M.P.; Pillay, K.; Chen, W.; Zondo, N.M.; Syed, P.R.; Mnguni, F.C.; Chiliza, Z.E.; Bamal, H.D.; Karpoormath, R. Similarities, variations, and evolution of cytochrome P450s in Streptomyces versus Mycobacterium. Sci. Rep. 2019, 9, 3962. [CrossRef]

56. Syed, P.R.; Chen, W.; Nelson, D.R.; Kappo, A.P.; Yu, J.-H.; Karpoormath, R.; Syed, K. Cytochrome P450 Monooxygenase CYP139 Family Involved in the Synthesis of Secondary Metabolites in 824 Mycobacterial Species. Int. J. Mol. Sci. 2019, 20, 2690. [CrossRef] [PubMed]

57. Agger, S.A.; Lopez-Gallego, F.; Hoye, T.R.; Schmidt-Dannert, C. Identification of sesquiterpene synthases from Nostoc punctiforme PCC 73102 and Nostoc sp. strain PCC 7120. J. Bacteriol. 2008, 190, 6084-6096. [CrossRef] [PubMed]

58. Kuhnel, K.; Ke, N.; Cryle, M.J.; Sligar, S.G.; Schuler, M.A.; Schlichting, I. Crystal structures of substrate-free and retinoic acid-bound cyanobacterial cytochrome P450 CYP120A1. Biochemistry 2008, 47, 6552-6559. [CrossRef] [PubMed]

59. Parvez, M.; Qhanya, L.B.; Mthakathi, N.T.; Kgosiemang, I.K.R.; Bamal, H.D.; Pagadala, N.S.; Xie, T.; Yang, H.; Chen, H.; Theron, C.W. Molecular evolutionary dynamics of cytochrome P450 monooxygenases across kingdoms: Special focus on mycobacterial P450s. Sci. Rep. 2016, 6. [CrossRef]

60. Nelson, D.R. Cytochrome P450 nomenclature. Methods Mol. Biol. (Clifton N. J.) 1998, 107, 15-24.

61. Nelson, D.R. Cytochrome P450 nomenclature, 2004. Methods Mol. Biol. (Clifton N. J.) 2006, 320, 1-10.

62. Nelson, D.R. The cytochrome p450 homepage. Hum. Genom. 2009, 4, 59-65. [CrossRef]

63. Feyereisen, R. Insect CYP genes and P450 enzymes. In Insect Molecular Biology and Biochemistry; Elsevier: Amsterdam, The Netherlands, 2012; pp. 236-316.

64. De Lima Procópio, R.E.; da Silva, I.R.; Martins, M.K.; de Azevedo, J.L.; de Araújo, J.M. Antibiotics produced by Streptomyces. Braz. J. Infect. Dis. 2012, 16, 466-471. [CrossRef]

65. Blin, K.; Shaw, S.; Steinke, K.; Villebro, R.; Ziemert, N.; Lee, S.Y.; Medema, M.H.; Weber, T. antiSMASH 5.0: Updates to the secondary metabolite genome mining pipeline. Nucleic Acids Res. 2019, 47, W81-W87. [CrossRef]

66. Alder, A.; Bigler, P.; Werck-Reichhart, D.; Al-Babili, S. In vitro characterization of Synechocystis CYP120A1 revealed the first nonanimal retinoic acid hydroxylase. FEBS J. 2009, 276, 5416-5431. [CrossRef]

67. Harada, H.; Shindo, K.; Iki, K.; Teraoka, A.; Okamoto, S.; Yu, F.; Hattan, J.; Utsumi, R.; Misawa, N. Efficient functional analysis system for cyanobacterial or plant cytochromes $\mathrm{P} 450$ involved in sesquiterpene biosynthesis. Appl. Microbiol. Biotechnol. 2011, 90, 467-476. [CrossRef] [PubMed]

68. Makino, T.; Otomatsu, T.; Shindo, K.; Kitamura, E.; Sandmann, G.; Harada, H.; Misawa, N. Biocatalytic synthesis of flavones and hydroxyl-small molecules by recombinant Escherichia coli cells expressing the cyanobacterial CYP110E1 gene. Microb. Cell Factories 2012, 11, 95. [CrossRef] [PubMed]

69. Torres, S.; Fjetland, C.R.; Lammers, P.J. Alkane-induced expression, substrate binding profile, and immunolocalization of a cytochrome P450 encoded on the nifD excision element of Anabaena 7120. BMC Microbiol 2005, 5, 16. [CrossRef] [PubMed]

70. Nelson, D.; Werck-Reichhart, D. A P450-centric view of plant evolution. Plant J. 2011, 66, 194-211. [CrossRef] [PubMed]

71. Tian, L.; DellaPenna, D. Progress in understanding the origin and functions of carotenoid hydroxylases in plants. Arch. Biochem. Biophys. 2004, 430, 22-29. [CrossRef] 
72. Kim, J.; Smith, J.J.; Tian, L.; DellaPenna, D. The evolution and function of carotenoid hydroxylases in Arabidopsis. Plant Cell Physiol. 2009, 50, 463-479. [CrossRef]

73. Kanehisa, M.; Sato, Y.; Furumichi, M.; Morishima, K.; Tanabe, M. New approach for understanding genome variations in KEGG. Nucleic Acids Res. 2018, 47, D590-D595. [CrossRef]

74. Marchler-Bauer, A.; Bo, Y.; Han, L.; He, J.; Lanczycki, C.J.; Lu, S.; Chitsaz, F.; Derbyshire, M.K.; Geer, R.C.; Gonzales, N.R. CDD/SPARCLE: Functional classification of proteins via subfamily domain architectures. Nucleic Acids Res. 2016, 45, D200-D203. [CrossRef]

75. Katoh, K.; Kuma, K.-i.; Toh, H.; Miyata, T. MAFFT version 5: Improvement in accuracy of multiple sequence alignment. Nucleic Acids Res. 2005, 33, 511-518. [CrossRef]

76. Boc, A.; Diallo, A.B.; Makarenkov, V. T-REX: A web server for inferring, validating and visualizing phylogenetic trees and networks. Nucleic Acids Res. 2012, 40, W573-W579. [CrossRef]

77. Letunic, I.; Doerks, T.; Bork, P. SMART 7: Recent updates to the protein domain annotation resource. Nucleic Acids Res. 2011, 40, D302-D305. [CrossRef] [PubMed]

78. Ngwenya, M.; Chen, W.; Basson, A.; Shandu, J.; Yu, J.-H.; Nelson, D.; Syed, K. Blooming of unusual cytochrome $\mathrm{P} 450$ s by tandem duplication in the pathogenic fungus Conidiobolus coronatus. Int. J. Mol. Sci. 2018, 19, 1711. [CrossRef]

79. Akapo, O.O.; Padayachee, T.; Chen, W.; Kappo, A.P.; Yu, J.-H.; Nelson, D.R.; Syed, K. Distribution and Diversity of Cytochrome P450 Monooxygenases in the Fungal Class Tremellomycetes. Int. J. Mol. Sci. 2019, 20, 2889. [CrossRef] [PubMed]

80. Saeed, A.; Sharov, V.; White, J.; Li, J.; Liang, W.; Bhagabati, N.; Braisted, J.; Klapa, M.; Currier, T.; Thiagarajan, M. TM4: A free, open-source system for microarray data management and analysis. Biotechniques 2003, 34, 374-378. [CrossRef] [PubMed]

(C) 2020 by the authors. Licensee MDPI, Basel, Switzerland. This article is an open access article distributed under the terms and conditions of the Creative Commons Attribution (CC BY) license (http://creativecommons.org/licenses/by/4.0/). 